\title{
THERMOREGULATORY SET POINT IN PATIENTS WITH SPINAL CORD INJURIES (SPINAL MAN) *
}

\author{
By M. Attia, B.Sc., D.I.H., M.Sc., Dr Rer. Physiol. ${ }^{1}$ and P. Engel, \\ M.D. ${ }^{2}$ \\ ${ }^{1}$ Assistant Professor, Department of Community Medicine and Behavioural Sciences, \\ Faculty of Medicine, Kuwait University, P.O. Box 24923, Kuwait. ${ }^{2}$ Professor, Head \\ of Rehabilitation Research Department, Institute of Work Physiology and Rehabilita- \\ tion Research, School of Medicine, University of Marburg, 3436 Hessisch Lichtenau, \\ Federal Republic of Germany.
}

Summary. The thermoregulatory set point in man can be estimated by the aid of quantifying thermal alliesthesial responses. Behavioural and autonomous thermoregulation in a group of nine patients with spinal cord transection was compared against a control group of six non-disabled under various room-climate conditions. Deviation of core temperature from thermoregulatory set point was estimated using a behavioural indicator (thermal alliesthesial responses) at different intervals of the exposure time. General thermal comfort sensation was rated on a subjective thermal comfort scale. The group with spinal cord transections showed, as expected, a state of partial poikilothermia. Mean skin temperature was approximately the same in both groups, but skin temperature distribution was different in the spinal cord transection when compared against the control group. The results of thermal alliesthesial responses indicated that core temperature for those with spinal cord transections were closer to their thermoregulatory set points than in the control group. It has been concluded that under conditions beyond thermal neutrality the spinal man may possess, some time after the injury, a thermoregulatory set point which varies directly with ambient thermal conditions. This phenomenon is viewed as an adaptive thermoregulatory process following spinal cord injury.

Key words: Spinal cord injured patients; Spinal man; Thermoregulatory set point; Adaptation; Thermal comfort.

\section{Introduction}

Patients with paraplegia and tetraplegia suffer from a condition of partial poikilothermia (Hutchinson, I 875; Paget, I885; Pembrey, I897; Gardiner \& Pembrey, I912; Holmes, I915; Sherrington, I924; Pollock et al., I95I; Tigay, 1956; Guttmann et al., 1958; White, 1959; Pledger, 1962; Downey et al., 1967, 1969, I973, 1976; Guttmann, 1976); they show lower core temperatures in the cold and higher core temperatures in the heat when compared against physically non-disabled. Most of the contributors confirmed that partial failure to maintain a constant core temperature independent of fluctuations in ambient temperature is due to the lack of an efficient system of vasoconstriction, vasodilation and sweating in the in-

* This work was done in the Institute of Work Physiology and Rehabilitation Research, in co-operation with Mrs Dr med. A. Witzenrath, head of the paraplegics station in the Orthopaedic Clinic and Rehabilitation Centre, Hessisch Lichtenau, F. R. of Germany. 
sentient portion of the body. During a warm water bath $\left(39 \cdot 2^{\circ} \mathrm{C}\right)$ for exposures for 40-45 minutes, Pollock et al. (I95I) observed that paraplegics showed a core temperature increase of $2.0^{\circ} \mathrm{C}$ compared against $0.9^{\circ} \mathrm{C}$ for the control group. Body temperature rise was thus brought about under conditions when heat loss by evaporation of sweat was prevented. The differences in core temperature rise observed between paraplegics and non-disabled may still be explained by the fact that the temperature gradient for heat transfer between the skin and the water bath was reduced in the case of the control non-disabled group due to their efficient ability to perform vasodilation.

Observations which may indicate that poikilothermia is associated with a shift in the thermoregulatory set point are few. Downey et al. (1969) suggested evidence for deep temperature-sensitive structures and that when paraplegics are exposed to central and skin cooling there is an apparent upward shift of the internal temperature at which increased heat production occurs. Indications that paraplegics may possess the ability to adjust their thermoregulatory set point in the presence of an external thermal stressor to facilitate a suitable level of adaptation to the thermal environment were recently reported (Attia et al., I982).

In this study thermal alliesthesial (Greek; Alloio = to alter or change, Aistesia $=$ sensation) reactions (Cabanac, I969) have been used as a thermoregulatory behavioural indicator in an attempt to demonstrate the presence of a possible change in the thermoregulatory set point in paraplegics exposed to various ambient thermal conditions. We are in agreement with the definition of the thermoregulatory set point proposed by Cabanac et al. (I97I), namely, that the thermoregulatory set point is that internal temperature at which neither heat loss mechanisms nor heat conservation mechanisms are activated. Internal temperatures above the set point then produce sweating and vasodilatation in man, and below the set point vasoconstriction and shivering are activated.

\section{Methods}

A set of 85 passive thermal exposures was performed on six patients with spinal cord transection, studied 6 months to 8 years after their injury (Table I), compared against nine non-disabled of the same age group.

Prior to the commencement of each exposure the bladders of the paraplegics were emptied. The experiments were performed in the morning in a climatic chamber in which ambient temperature, relative humidity and air speed were controlled and wall temperature was approximately equal to air temperature. All subjects were dressed in light summer costumes of an estimated 0.4 Clo-value. The subjects were exposed to a constant room temperature for 45 minutes on different days at the same time of day in the climatic chamber. Each subject was exposed to a total of six ambient temperatures, namely, I5, 20, 25, 30, 35 and $40^{\circ} \mathrm{C}$; air speed $(0.2-0.3 \mathrm{~m} / \mathrm{s})$ and relative humidity (45 per cent) were kept constant. Every exposure was preceded by a i 5-minute fore-chamber exposure. The subjects were sitting comfortably on wheel chairs.

A set of 5-second local temperature stimuli of $15,20,25,30,35$ and $38^{\circ} \mathrm{C}$ was applied on the hand, forehead and back of neck. A twominute interval between each stimulus and the other was observed, so 
TABLE I

Characteristics of the six subjects with spinal cord transections

\begin{tabular}{ccccc}
\hline Subject & Sex $^{\star}$ & Age, yr & Level cord lesion & Time since injury \\
\hline ZA & $\mathrm{M}$ & 22 & $\mathrm{~L} 5 / \mathrm{S}_{\mathrm{I}}$ & 5 years \\
$\mathrm{NE}$ & $\mathrm{M}$ & 28 & $\mathrm{~T} 4 / 5$ & 8 years \\
$\mathrm{KO}$ & $\mathrm{F}$ & $2 \mathrm{I}$ & $\mathrm{LI}$ & 6 months \\
$\mathrm{HO}$ & $\mathrm{M}$ & 30 & $\mathrm{C} 7$ & I I months \\
$\mathrm{KI}$ & $\mathrm{F}$ & $\mathrm{I} 5$ & $\mathrm{~T} 6$ & 9 months \\
$\mathrm{KR}$ & $\mathrm{M}$ & 23 & $\mathrm{~T} 3 / 4$ & 8 months \\
${ }^{\star} \mathrm{M}=$ male, $\mathrm{F}=$ female & & \\
\end{tabular}

that the skin stimulated regained its basal temperature before the next stimulus was applied. For each stimulus the subjects rated their degree of local thermal pleasantness/unpleasantness on the following psychophysical five point scale:^

\begin{tabular}{|c|c|c|}
\hline Very Pleasant & (Very Comfortable) & $+2 \cdot 0$ \\
\hline Pleasant & (Comfortable)... & $+I \cdot O$ \\
\hline Indifferent & (Indifferent). & 0.0 \\
\hline Unpleasant & (Uncomfortable). & $-\mathbf{I} \cdot \mathbf{O}$ \\
\hline Very Unpleasant & 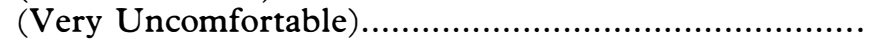 & $-2 \cdot 0$ \\
\hline
\end{tabular}

$\star$ Rating between the integers using decimals was possible.

A Peltier thermode (Engel et al., I979; Attia et al., I980-b; Hildebrandt et al., I98I) $5.5 \mathrm{~cm}$ long and $2.7 \mathrm{~cm}$ wide was used to apply the temperature stimuli. The subjects also indicated their most pleasant temperature on the back of the neck by voluntary control, using the temperature control knob of the thermode without looking at the temperature scale. The subjects also rated their level of satisfaction/dissatisfaction with the thermal environment on the same five point scale ranging from $+2 \cdot 0$ for very comfortable to $-2 \cdot 0$ for very uncomfortable.

This procedure was performed at the start (in the fore-chamber) and repeated every IO-I5 minutes throughout the exposure time. Rectal temperature and skin temperature at eight locations were continuously recorded using thermistors and two multipen recorders.

\section{Quantification methods of thermal alliesthesia}

Alliesthesia was defined as 'the changed sensation for a given peripheral stimulus resulting from the stimulation of internal sensors' (Bligh and Johnson, I973). Thermal alliesthesia was first defined by Cabanac (I969) as the pleasure/displeasure sensation aroused by a given temperature stimulus 
according to the internal thermal state of the subject. A temperature stimulus provokes an affective and a discriminative sensation; the discriminative aspect is a function of the nature, intensity and duration of the stimulus; whereas the affective part is the amount of pleasure/displeasure aroused by the stimulus (Young, I959; Cabanac, 1979). If a subject is offered a set of temperature stimuli, provoking a discriminative sensation ranging from cold to warm, his affective sensation would depend on the skin temperature and the deviation of his core temperature from the thermoregulatory set point (Cabanac, I969; Cabanac et al., I97 I; Strempel et al., I976; Cabanac, I979; Engel et al., I979, I980; Attia et al., I980-a). When cold stimuli are pleasant and warm stimuli unpleasant, body temperature is found to be above the set point; when warm stimuli are perceived as pleasant and cold stimuli as unpleasant, body temperature is below the set point (Cabanac et al., I97I; Cabanac et al., I976; Strempel et al., I976; Engel et al., I979; Attia et al., I980-a). Under conditions of thermal neutrality, however, the temperature stimuli would provoke affective sensations more or less close to 'indifferent' for the range of discriminative sensation from cool to warm (Hensel, I979).

A semi-schematic typical example of pleasantness rating using the five point psychophysical scale plotted against time of exposure for every temperature stimulus is given in Figure I Top. For each set of temperature stimuli, the so-called rating/stimulus regression line can be calculated to determine the regression coefficient or slope (Fig. I Middle). A positive slope shows that the subject is hypothermic and a negative slope shows that the subject is hyperthermic (Strempel et al., 1976; Cabanac et al., I976; Engel et al., 1979; Attia et al., 1980-b). This is to be expected since a hypothermic subject would perceive a cool stimulus as unpleasant. A condition exists for which the slope of rating/stimulus line is zero indicating that the subject is at a state when his body temperature is neither higher nor lower than his thermoregulatory set point. A plot of rating/stimulus slope against time of exposure (Fig. I Bottom) would reveal the thermal state of the subject with respect to the thermoregulatory set point at any point in time throughout the exposure.

\section{Results}

The rating/stimulus slope for the control group is a sigmoid curve showing a sharp point of intersection with the $a=0.0$ horizontal line (Fig. $2 \mathrm{~A}$ ), with negative rating/stimulus slopes at high room temperatures. Paraplegics, however, show rating/stimulus slopes closer to the zero $(a=0.0)$ line than the control group especially at high room temperatures (Fig. 2A).

Figure $2 \mathrm{~B}$ confirms the well known state of partial poikilothermia in paraplegics. The control group maintained a fairly constant rectal temperature during all exposures, whereas paraplegics had lower core temperatures in the cold and higher core temperatures in the heat.

The inverse proportionality existing between most pleasant temperature and room temperature (Attia et al., I980-a) is more clearly observed in non-disabled than in paraplegics (Fig. 2C). For the range of room temperature from $15^{\circ} \mathrm{C}$ to $40^{\circ} \mathrm{C}$ paraplegics indicated their most pleasant temperatures on the back of their neck by voluntary control, in the average 


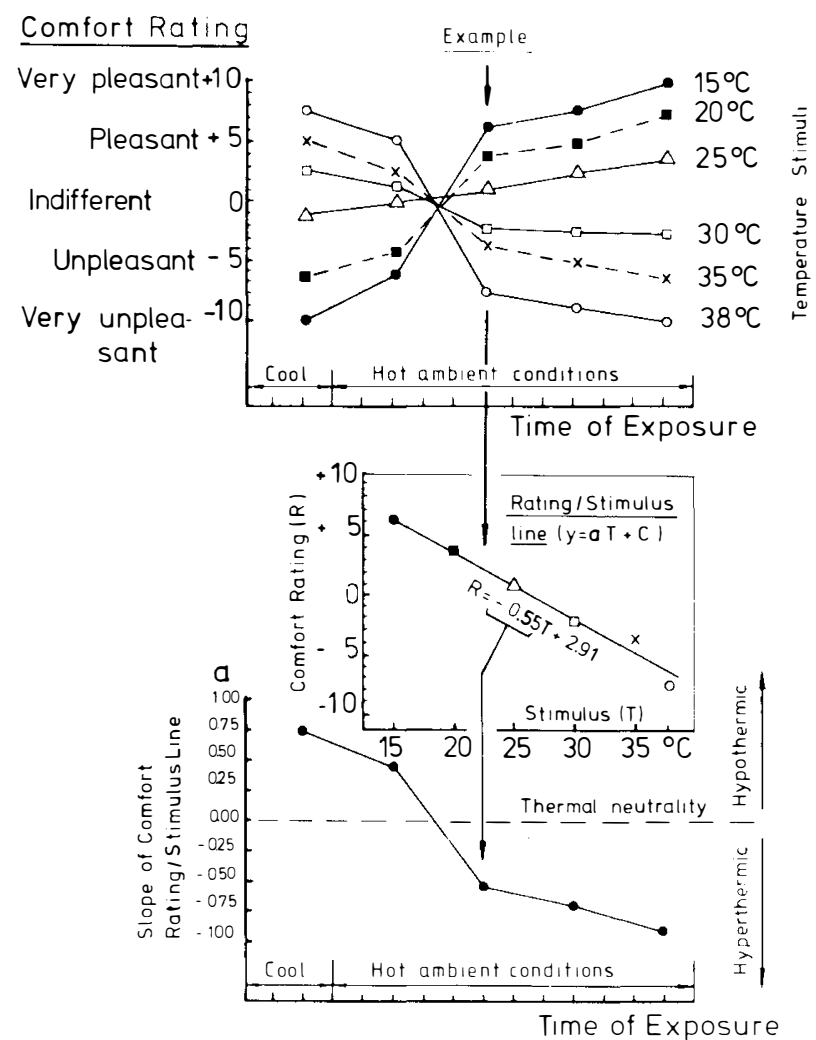

FIG. I

Semi-schematic diagram for a subject exposed to a cool ambient atmosphere and thereafter to a hot ambient temperature. Top: pleasantness/displeasantness rating plotted against time of exposure for each stimulus of $15,20,25,30,35$, and $38^{\circ} \mathrm{C}$. Middle-box: rating/stimulus regression line calculated to determine the slope for each set of temperature stimuli. Bottom: slope of pleasantness rating/stimulus line plotted against time of exposure.

between $35^{\circ} \mathrm{C}$ and $29^{\circ} \mathrm{C}$, compared against a wider range from $38^{\circ} \mathrm{C}$ to $23^{\circ} \mathrm{C}$ for non-disabled.

The general thermal comfort sensation rating of paraplegics shows that they perceived low temperatures as being slightly more comfortable than the control group (Fig. 2D). At high room temperatures paraplegics had a general discomfort sensation rating similar to the control group, whereas, at $30^{\circ} \mathrm{C}$ room temperature, the mean rating of the control group was close to 'indifferent' as compared to a mean rating of 'uncomfortable' for the paraplegic group.

The mean rectal temperature and mean skin temperature for the six paraplegics and six non-disabled control group were plotted against time of exposure for two room temperatures, $20^{\circ} \mathrm{C}$ and $35^{\circ} \mathrm{C}$ in Figure 3 which illustrates that the non-disabled maintained a fairly constant core temperature with a decrease of $0.3^{\circ} \mathrm{C}$ during the exposure to the ambient atmosphere 

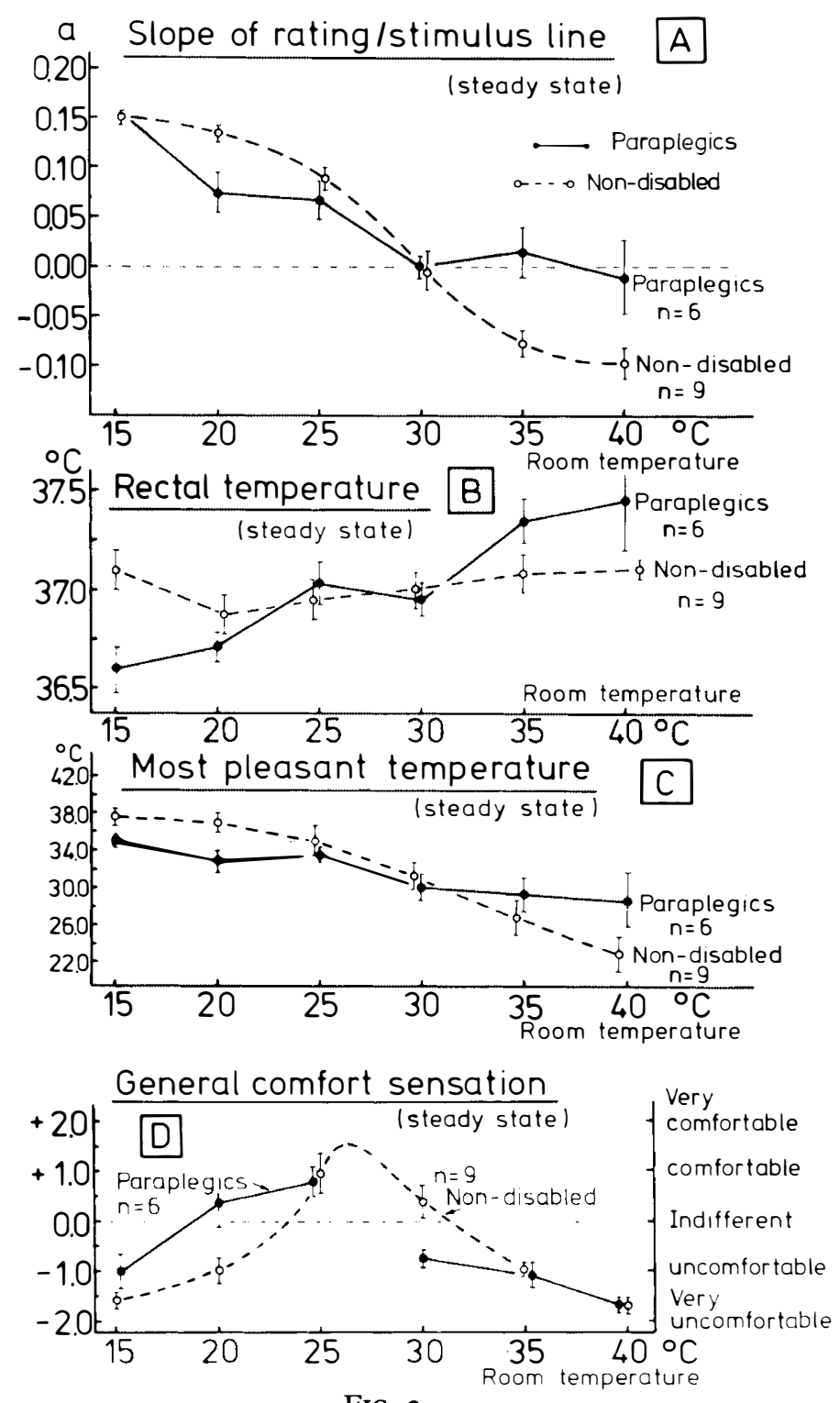

FIG. 2

Mean \pm s.e. of rating/stimulus slope (A), rectal temperature (B), most pleasant temperature (C), and general comfort sensation vote (D) plotted against room temperature for a group of six paraplegics and a control group of non-disabled.

of $20^{\circ} \mathrm{C}$. Paraplegics showed an increase of about $0.4^{\circ} \mathrm{C}$ and a decrease of $0.2^{\circ} \mathrm{C}$ in rectal temperature during the $35^{\circ} \mathrm{C}$ and $20^{\circ} \mathrm{C}$ room temperatures respectively. Core temperature difference at the end of the $20^{\circ} \mathrm{C}$ and $35^{\circ} \mathrm{C}$ exposures was $0.62^{\circ} \mathrm{C}$ for paraplegics, whereas for the control group the difference was $0 \cdot 2^{\circ} \mathrm{C}$ (Fig. 3 Top). 


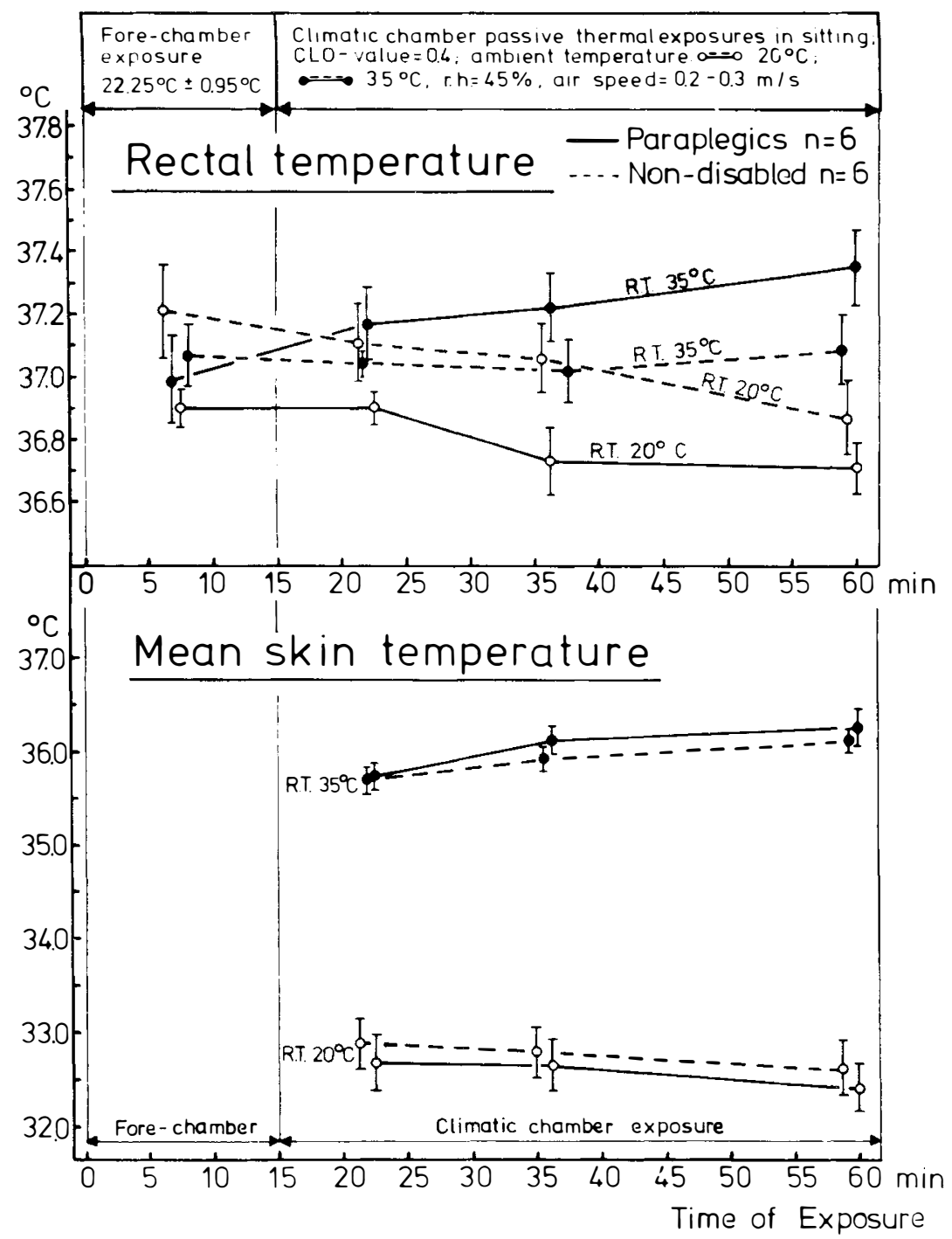

FIG. 3

Mean \pm s.e. of rectal temperature and mean skin temperature plotted against time of exposure for six spinal cord transections and a control group of six non-disabled.

Mean skin temperature was calculated using a formula proposed by Nadel (1977) which considers both area and sensitivity weighting:

$$
\begin{array}{rll}
\mathrm{T}_{\text {skin }} & =0.2 \mathrm{I} \mathrm{T}_{\text {face }}+0.17 \mathrm{~T}_{\text {abdomen }}+0.1 \mathrm{I} \mathrm{T}_{\text {chest }} \\
& +0.10 \mathrm{~T}_{\text {back }}+0.15 \mathrm{~T}_{\text {thigh }} & +0.08 \mathrm{~T}_{\text {calf }}+0.12 \mathrm{~T}_{\text {upper arm }} \\
& +0.06 \mathrm{~T}_{\text {lower arm }}
\end{array}
$$

No significant differences in mean skin temperature between the paraplegics and the control group were observed (Fig. 3 Bottom). 

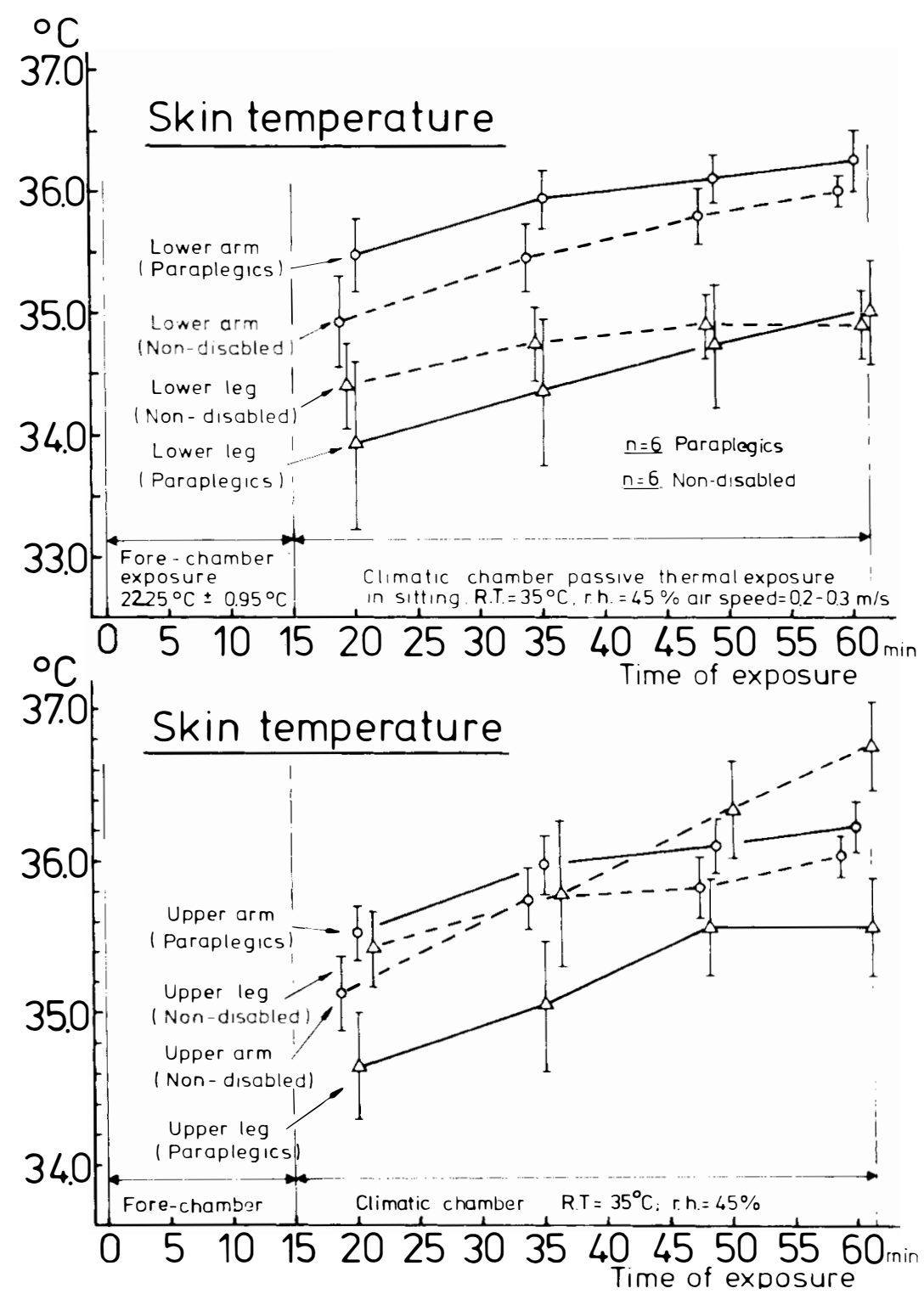

FIG. 4

Mean \pm s.e. skin temperature on lower and upper leg and lower and upper arm plotted against time of exposure for a group of six spinal cord transections compared against a control group of six non-disabled.

Skin temperature distribution on the sentient and insentient portions showed considerable variations. An example of two locations on the sentient extremities (lower and upper arm) and two locations on the unsentient extremities (lower and upper leg) for two different room temperatures, $20^{\circ} \mathrm{C}$ and $35^{\circ} \mathrm{C}$, are shown in Figures 4 and 5 . At $35^{\circ} \mathrm{C}$ room temperature paraplegics showed lower leg temperatures increasing linearly with time of 


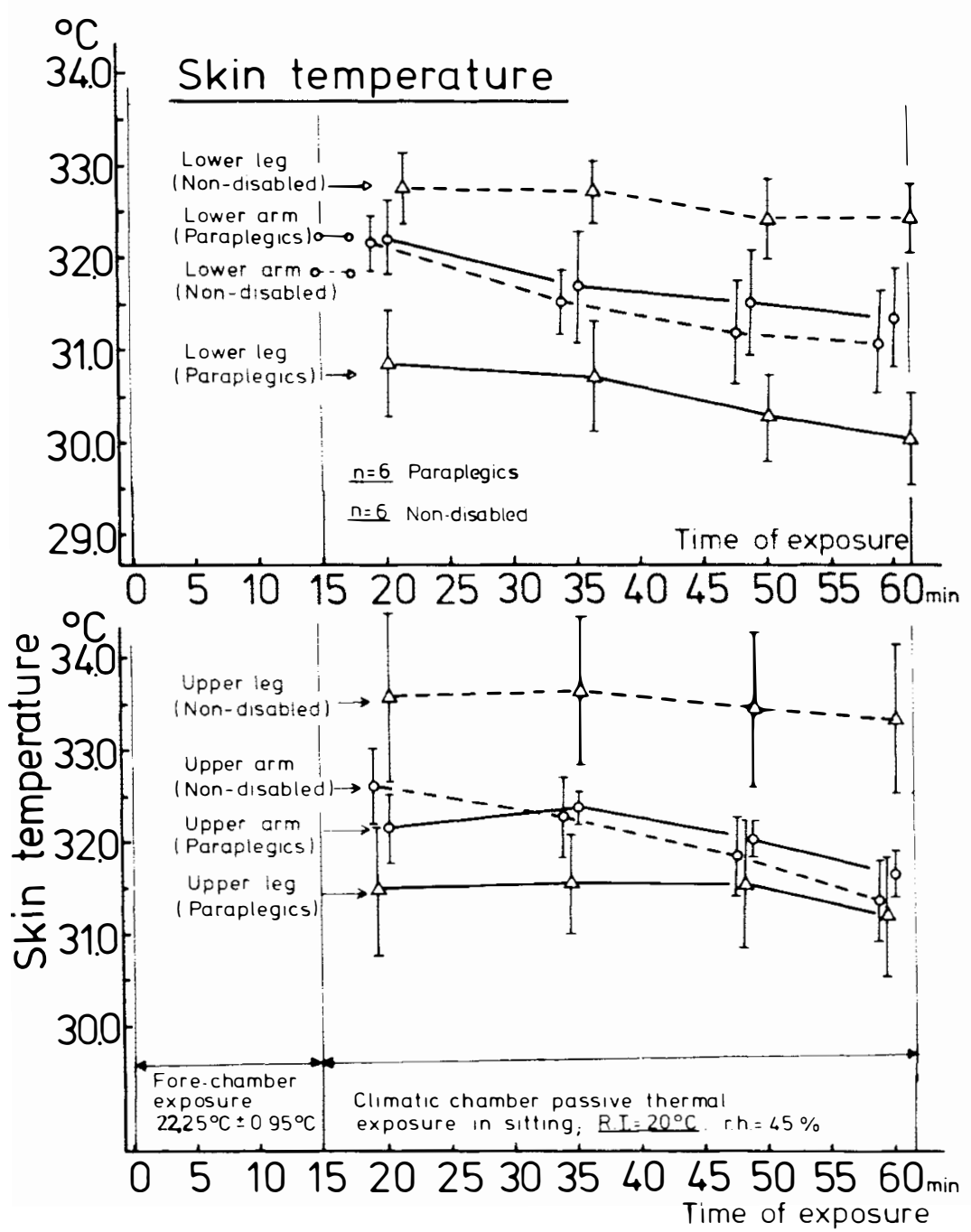

FIG. 5

Mean \pm s.e. skin temperature on lower and upper leg and lower and upper arm plotted against time of exposure for a group of six spinal cord transections compared against a control group of six non-disabled.

exposure from $33.9^{\circ}$ to $34.95^{\circ} \mathrm{C}$ compared against $34.4^{\circ} \mathrm{C}$ at the beginning of the exposure with a linear increase up to $34^{\circ} 9^{\circ} \mathrm{C}$ observed after 35 minutes of exposure, for the control group (Fig. 4 Top). The lower arm temperature however, was higher in paraplegics (from $35.5^{\circ}$ to $36.25^{\circ} \mathrm{C}$ ) than in the control group (from $34.9^{\circ}$ to $36.0^{\circ} \mathrm{C}$ ). The temperature difference between lower arm and lower leg for paraplegics was $\mathrm{I} \cdot 5^{\circ} \mathrm{C}$ at the beginning of the exposure, followed by a decreasing tendency starting after 20 minutes until the difference reached $\mathrm{I} \cdot 0^{\circ} \mathrm{C}$ at the end of the exposure (Fig. 4 Top). Conversely, the temperature difference between lower leg and lower arm for the control group was $0.5^{\circ} \mathrm{C}$ at the beginning followed by a continuous 
increasing tendency until it reached $\mathrm{I} \cdot \mathrm{I}^{\circ} \mathrm{C}$ at the end of the exposure (Fig. 4 Top).

The upper leg and upper arm skin temperature in paraplegics showed a similar tendency to their lower arm and lower leg, namely, a temperature difference decrease from $0.9^{\circ} \mathrm{C}$ at the beginning to $0.6^{\circ} \mathrm{C}$ at the end of the exposure (Fig. 4 Bottom). It is to be noted that there is a levelling tendency of skin temperature above room temperature for paraplegics (Fig. 4 Bottom). Upper leg skin temperature for non-disabled increased linearly from $35.4^{\circ} \mathrm{C}$ to $36.7^{\circ} \mathrm{C}$ whereas the upper arm showed a levelling tendency. Skin temperature difference between the upper arm and upper leg was similar to the skin temperature difference between lower arm and lower leg. The control group showed a difference between upper arm and upper leg which was smaller at the beginning $\left(0.3^{\circ} \mathrm{C}\right)$ than at the end of the exposure $\left(0.75^{\circ} \mathrm{C}\right)$, the upper leg temperature was higher than the upper arm (Fig. 4 Bottom).

An example of skin temperature distribution in paraplegics and nondisabled at a room temperature of $20^{\circ} \mathrm{C}$ is shown in Figure 5 .

Both the lower and upper arm skin temperatures for paraplegics and their control group were more or less equal. On the other hand, the upper leg and lower leg skin temperatures in the control were significantly higher (about $2.0^{\circ} \mathrm{C}$ ) than in paraplegics. The temperature difference between lower arm and lower leg (Fig. 5 Top) and between upper arm and upper leg (Fig. 5 bottom) for the control group increased from the beginning $\left(0 \cdot 6^{\circ}\right.$ to $\left.\mathrm{I} \cdot \mathrm{O}^{\circ} \mathrm{C}\right)$ to the end $\left(\mathrm{I} \cdot 3^{\circ}\right.$ to $\left.2 \cdot 0^{\circ} \mathrm{C}\right)$ of the exposure. Conversely, this difference in paraplegics was either constant $\left(\mathrm{I} \cdot 3^{\circ} \mathrm{C}\right)$ or decreased from $0.7^{\circ}$ to $0.4^{\circ} \mathrm{C}$.

Figure 6 shows the mean values of the slope of rating/stimulus line, most pleasant temperature and general thermal comfort sensation plotted against time of exposure for the paraplegic and the control groups. The results were obtained during climatic chamber exposures to two ambient temperatures, $20^{\circ} \mathrm{C}$ and $35^{\circ} \mathrm{C}$. The fore-chamber ambient thermal conditions were not controlled, they varied with respect to room temperature, air speed and relative humidity. Thus, the pre-chamber results do not present a good basis for a comparison between the two groups.

The rating/stimulus slope obtained from the pleasantness rating in response to the temperature stimuli offered is shown in Fig. 6A for the two groups. Both groups showed positive rating/stimulus slopes during the pre-chamber exposure. The rating/stimulus slope for paraplegics decreased from $+0 . \mathrm{II}^{\circ} \mathrm{C}$ at the beginning of the exposure to $+0.08^{\circ} \mathrm{C}$ at the end. The control group showed a slight increase from $+0 \cdot 12^{\circ}$ to $+0 \cdot 14^{\circ} \mathrm{C}$ (Fig. 6A).

During the exposure to the room temperature of $35^{\circ} \mathrm{C}$, the control group showed a decreasing tendency in the slope of rating/stimulus line (Fig. 6A) from a positive value $\left(+0 \cdot 10^{\circ} \mathrm{C}\right)$ during the pre-chamber conditions to increasingly negative values throughout the time of exposure whereas the rating/stimulus slopes for paraplegics were very close to the zero line $(\mathrm{a}=0.0)$.

The results of the most pleasant temperature, chosen by voluntary control on back of neck for both groups, confirmed the result obtained from rating/stimulus regression analysis. The difference between most pleasant temperatures chosen respectively at $20^{\circ} \mathrm{C}$ and $35^{\circ} \mathrm{C}$ ambient temperatures 


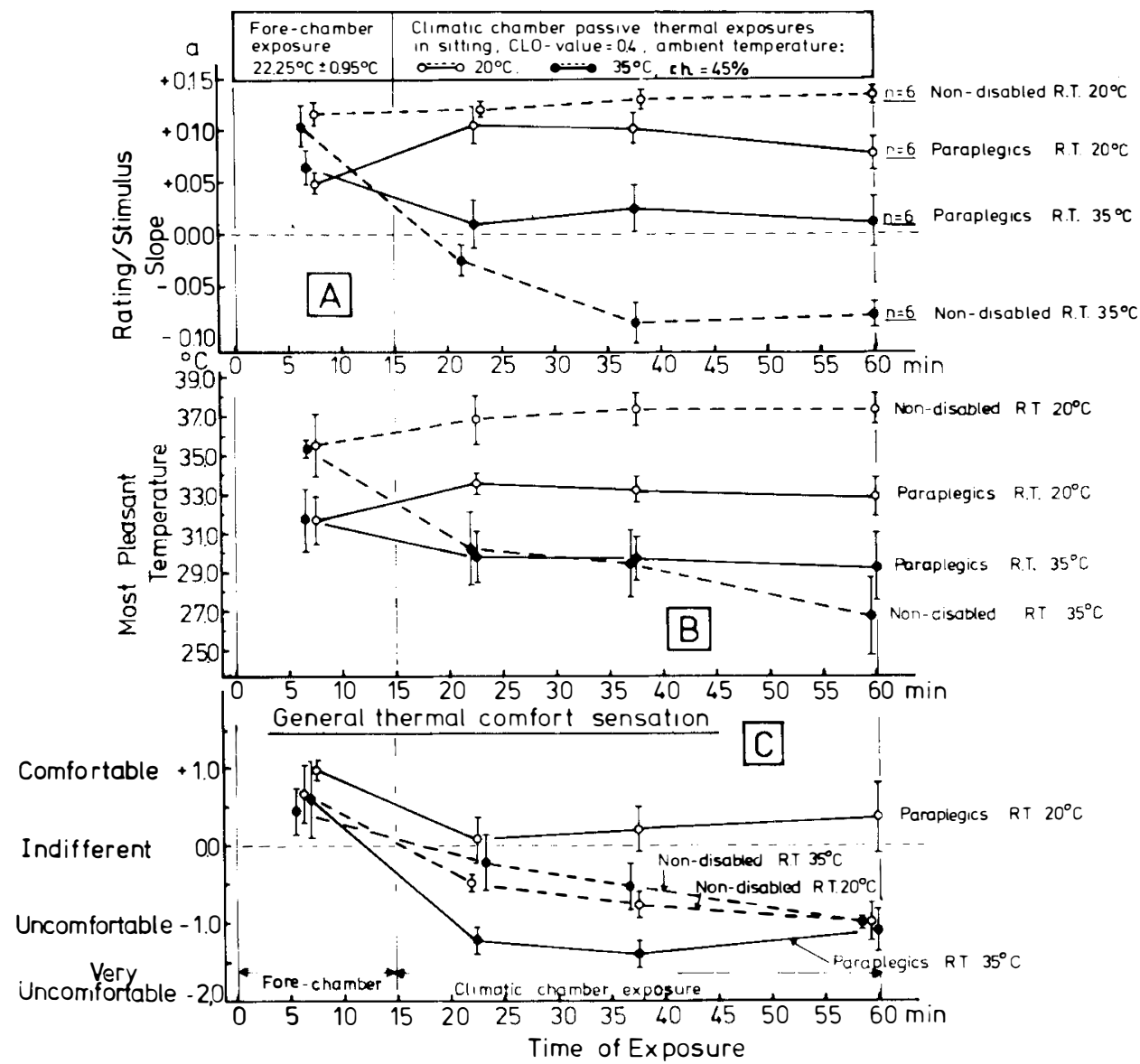

FIG. 6

Mean \pm s.e. rating/stimulus slope (A), most pleasant temperature (B), and general thermal comfort sensation (C) plotted against time of exposure for a group of six spinal cord transections and a control group of six non-disabled.

(Fig. 6B) were significantly smaller in the case of paraplegics $\left(3.3^{\circ} \mathrm{C}\right)$ than the control group $\left(10 \cdot 7^{\circ} \mathrm{C}\right)$.

General thermal comfort sensation vote for the two groups is shown in Fig. 6C. Paraplegics' comfort vote at $35^{\circ} \mathrm{C}$ room temperature was from the start close to 'very uncomfortable', with a slight decrease in discomfort at the end of the exposure (Fig. 6C). For a room temperature of $20^{\circ} \mathrm{C}$ paraplegics rated their thermal comfort close to 'indifferent' throughout the exposure time. Thermal comfort sensation rating of the control group for both room temperatures decreased slowly with time of exposure from the pre-chamber conditions $\left(+0.5^{\circ} \mathrm{C}\right.$ i.e. slightly comfortable) to the end of the exposure $\left(-\mathrm{I} \cdot 0^{\circ} \mathrm{C}\right.$ i.e. uncomfortable).

\section{Discussion and Conclusions}

A comprehensive discussion of thermoregulatory and blood flow dis- 
turbances in the spinal man was presented by Guttmann (I976) who stated that maintenance of homeothermia in man depends on the nervous integration and co-ordinated function of three systems, namely:

I. Surface receptor system;

2. Afferent transmitter system;

3. Efferent transmitter system.

Paraplegics and tetraplegics suffer from a disturbance in the three systems in their insentient portion of the body and therefore show symptoms of poikilothermia (Hutchinson, I 875; Paget, I 885; Pembrey, I 897; Gardiner \& Pembrey, I9I2; Holmes, I9I 5; Sherrington, I924; Pollock, I95I; Tigay, I956; Guttmann et al., I958; White, I959; Pledger, I962; Downey et al., 1967, I969, I973, I976, Guttmann, I976).

Another aspect of thermoregulation in man is thermoregulatory behaviour. The total thermoregulatory response $(R)$ is the sum of both thermoregulatory autonomous or physiological responses $(\mathrm{Ph})$ and thermoregulatory behavioural reactions $(\mathrm{Be})$ :

$$
\mathrm{R}=\mathrm{Ph}+\mathrm{Be} \ldots \ldots \ldots \ldots \ldots \ldots \text { (Hardy, 1972). }
$$

Thermal balance is achieved in such a way that thermoregulatory physiological strain is minimized (Hardy, I972). In other words, behavioural responses modify the need for physiological or autonomous response (Hensel et al., I973).

Non-disabled people are mobile, whereas people who are paraplegic or tetraplegic are practically immobile without an external aid or device such as a wheel chair. Non-disabled tend to follow Hardy's 1972 hypothesis by minimizing their thermoregulatory physiological strain through mobility and behaviour; whereas paraplegics rely on their autonomous thermoregulatory response, especially in the sentient portion of the body.

Physiological thermoregulatory response $(\mathrm{Ph})$ can be estimated by the measurement of physiological indicators such as core temperature, skin temperature, metabolic rate, sweating onset and rate, blood flow, vasoconstriction, vasodilation, and shivering. The thermoregulatory behavioural responses are difficult to quantify, but measurement of thermal alliesthesial reactions may give an indication of the direction and magnitude of the thermoregulatory behavioural output of the human 'thermostat'.

The direction and magnitude of thermal alliesthesial reactions depend on skin temperature and the deviation of the prevailing core temperature from a reference temperature or set point (Table II) (Cabanac et al., I97 I; Strempel et al., I976; Cabanac et al., I976; Engel \& Attia, I980); thus, it is possible to write:

a or $T_{\text {most pleasant }}=f\left(\Delta T_{\text {core }}, \bar{T}_{\text {skin }}\right)$

where

$\mathrm{a}=$ the slope of rating/stimulus regression line

$\mathrm{T}_{\text {most pleasant }}=$ most pleasant temperature

$\Delta T_{\text {core }}=$ deviation of core temperature from thermoregulatory set point

$\overline{\mathrm{T}}_{\text {skin }}=$ mean skin temperature.

In complete paraplegics and tetraplegics the role of skin temperature for thermal alliesthesia reactions is most probably limited to the sentient portion of the body. The insentient portion of the body is a temperature 
non-regulating system, which acts under extreme thermal ambient conditions like a 'heat-exchanger' (Downey et al., I97 I, 1973), tending to increase or decrease core temperature, depending on ambient thermal condititions. Moreover, the thermoregulatory load of the sentient portion of the body would increase to offset the additional thermal load resulting from the 'heat exchanger' role played by the insentient portion of the body until steady state is reached.

\section{TABLE II}

Schematic qualitative relationships between core temperature mean skin temperature, and most pleasant temperature (glove). The table was based on a set of 35 observations on a group of non-disabled by Cabanac et al., I 976.

\begin{tabular}{|c|c|c|}
\hline $\begin{array}{c}\text { Core } \\
\text { temperature }\end{array}$ & $\begin{array}{c}\text { Mean skin } \\
\text { temperature }\end{array}$ & $\begin{array}{c}\text { Most pleasant } \\
\text { temperature glove }\end{array}$ \\
\hline$\downarrow$ & $\downarrow$ & $\uparrow$ \\
\hline$\uparrow$ & $\downarrow$ & $\downarrow$ \\
\hline$\downarrow$ & $\rightarrow$ & $\uparrow$ \\
\hline$\uparrow$ & $\rightarrow$ & $\downarrow$ \\
\hline$\rightarrow$ & $\uparrow$ & $\downarrow$ \\
\hline$\rightarrow$ & $\downarrow$ & $\uparrow$ \\
\hline \multicolumn{2}{|c|}{ Abbreviations Rise $\uparrow$ : Fall $\downarrow:$ No change $\rightarrow$} \\
\hline
\end{tabular}

Application of this information to paraplegics would mean that apart from the range of ambient temperatures $\left(25^{\circ} \mathrm{C}\right.$ and $\left.30^{\circ} \mathrm{C}\right)$, for which paraplegics showed constant core temperature (Fig. 2B), core temperature overrides the effect of skin temperature on thermal alliesthesial reactions. In ambient atmospheres below and above this range, paraplegics show clear changes in core temperature compared against the control group (Fig. 2B). It can therefore be argued that above and below the conditions of thermal neutrality, alliesthesial reactions in paraplegics are determined solely by core temperature:

$$
\text { a or } T_{\text {most pleasant }}=f\left(\Delta T_{\text {core }}\right)
$$

Engel (I982) argued that functional or anatomical loss of extremities causes a shift in the body area/volume relationship towards less optimum thermoregulatory responses to endogenous and/or exogenous thermal loads. He studied a group of amputees and a group with congenital maldevelopment of limbs (dysmelees) exposed to passive thermal and work loads and concluded that symptoms of thermoregulatory adaptive changes may be observed in the two groups. Long term thermoregulatory adjustments following functional loss of extremities in paraplegics was studied in comparison to a control group of non-disabled (Engel et al., 1978). Both groups underwent periodic passive thermal and work exposure tests. The results were interpreted as evidence for a long term thermoregulatory adaptative process following spinal cord injuries.

The present study indicates that, some time after the injury (6 months or more): 
I. Paraplegics may possess the capability of adjusting their thermoregulatory set point in the presence of an external ambient stressor. The sentient skin temperature and core temperature changes determine in which direction and to what extent such a change in the thermoregulatory set point is necessary. Rawson and Hardy (1967) showed that sweating inhibition in a paraplegic patient was not achieved by cooling of the leg; whereas in a non-disabled control subject sweating inhibition was possible with less cooling of the leg. A fact which indicates that the signal for thermoregulatory processes in paraplegics is independent of skin temperature of the insentient parts of the body. Similar evidence was provided by Downey et al. (1967, I969, I97I, I973, I976) using the insentient portions of the body as a 'heat exchanger' to produce changes in core temperature or to keep core temperature constant while heating or cooling the sentient portion.

2. The change of thermoregulatory set point varies directly with ambient thermal conditions. At higher ambient temperatures the thermoregulatory set point of paraplegics is raised and at lower ambient thermal conditions the thermoregulatory set point is decreased. At neutral temperatures paraplegics have the same thermoregulatory set point as nondisabled (Figs. 2A and 2C). Furthermore Downey et al. (I967) argued that their experiments have shown that when the deep body temperature fell below $36^{\circ} \mathrm{C}$, shivering was initiated. The exact temperature of this set point with the techniques he used probably cannot be defined too closely and would have to be considered as a range from $35.5-36 \cdot 0^{\circ} \mathrm{C}$, with apparent variation between individuals and from day to day. Downey et al. (1967) concluded that their results were in the contrast to the studies carried out by Benzinger (I962) and Snell (1954) who found a more exact shivering set point around $36 \cdot 8^{\circ} \mathrm{C}$.

In view of the facts that the groups studied by Benzinger (I962) \& Snell (I954) were non-disabled while the group studied by Downey et al. (I967) were patients with chronic cervical cord transection, the comparison between these groups is difficult. It is our contention that the thermoregulatory system in these groups are not comparable. The results of our study may provide evidence for the explanation of this difference, namely, paraplegics possess, some time after the injury, the ability to decrease their thermoregulatory set point and thus their shivering threshold.

\section{RÉSUMÉ}

Il a été montré qu' on peut estimer la consigne du thermostat humain par les résponses quantitatives d'alliesthésie thermique. On a comparé ici les résponses thermorégulatrices autonomes er comportementales chez 6 sujets paraplégiques et un groupe de sujets témoins sains. La déviation de la température profonde vis à vis de sa consigne est estimée grâce à un indice comportemental (l'alliesthésie thermique) à diffèrents intervalles pendant l'expérience. Le confort thermique global est estimé par le sujet et exprimé sur une échelle subjective.

Le groupe de paraplégiques montre, comme on s'y attendait, une certaine poikilothermie. La température cutanée moyenne était comparable dans les deux groupes, mais la distribution des températures cutanées était différente d'un groupe à l'autre. Les résponses alliesthésiques indiquaient une température profonde plus proche de sa consigne chez les paraplégiques que chez les témoins.

On en conclut que le paraplégique pourrait posséder après un délai suivant la section spinale, une consigne thermorégulatrice qui varie directement avec les conditions thermiques ambiantes. Ce phénoméne est considéré comme un processus thermorégulateur adaptatif après section spinale. 


\section{ZUSAMMENFASSUNG}

Es hat sich gezeigt, daß der thermoregulatorische Sollwert durch die Bestimmung der thermischen alliesthesischen Reaktionen ermittelt werden kann. Die thermischen Verhaltensreaktionen und die autonome Thermoregulation sind in einer Gruppe von 6 Querschnittgelähmten mit einer Kontrollgruppe von Nichtbehinderten bei verschiedenen Raumtemperaturen verglichen worden. Die Abweichung der Kerntemperatur vom thermoregulatorischen Sollwert wurde mittels eines Verhaltensindikators (thermische alliesthesische Reaktionen) in verschiedenen Intervallen ermittelt. Außerdem wurde der gesamte thermische Komfort auf einer thermischen Komfortskala gewählt. Wie erwartet, zeigen die Querschnittgelähmten eine partielle Poikilothermie. Die mittlere Hauttemperatur war in beiden Gruppen gleich, die Verteilung der Hauttemperaturen an Rumpf und Extremitäten jedoch in beiden Gruppen unterschiedlich. Der thermoregulatorische Sollwert bei Querschnittgelähmten ist direkt von der Umgebungstemperatur abhängig. Die Ergebnisse der thermischen alliesthesischen Reaktionen weisen darauf hin, daß die Kerntemperatur von Querschnittgelähmten näher bei ihrem thermoregulatorischen Sollwert liegt als bei Nichtbehinderten. Man kann daraus schließen, daß Querschnittgelähmte vermutlich einige Zeit nach der Verletzung in der Lage sind, außerhalb der thermischen Neutralitätszone ihren thermoregulatorischen Sollwert zu verstellen. Dieses Phänomen könnte als ein adaptiver thermoregulatorischer Prozeß aufgefaßt werden.

\section{Acknowledgements}

Acknowledgement is gratefully made to Professor M. Cabanac and Professor G. Hildebrandt for revising the manuscript. The authors are also grteful to Mrs I. Webeling who was helpful indeed in carrying out the experiments with the paraplegics.

\section{REFERENCES}

Attia, M., Engel, P., Hildebrandt, G. (I980-a). Thermal comfort during work; a function of time of day. Int. Arch. Occup. Envir. Hlth., 45, 205-2 15.

Attia, M., Engel, P., Hildebrandt, G. (I980-b). Quantification of thermal comfort parameters using a behavioural indicator. Physiol. Behav., 24(5), $90 \mathrm{I}-909$.

Attia, M., Engel, P., Hildebrandt, G. (I982). Assessment of thermal comfort parameters using a behavioural indicator with special reference to physically disabled. In Hildebrandt \& Hensel, (eds.): Biological Adaptation. Thieme Verlag Stuttgart. pp. 2I 2-2I5.

BENZINGER, T. H. (1962). The thermostatic regulation of human heat production and heat loss. Proc. Intern. Congr. Physiol., Leiden, ool I, p. 415.

Bligh, J. \& Johnson, K. G. (I973). Glossary of terms for thermal physiology. f. Appl. Physiol., 35, 94I-96I.

Cabanac, M. (1969). Plaisir ou Deplaisir de la Sensation Thermique et Homothermie. Physiol. Behav., 4, 359-364.

Cabanac, M., Cunningham, D. J., Stolwijk, J. A. J. (I97I). Thermoregulatory set point during exercise; a behavioural approach. F. Comparat. Physiol. Psychol., 76(I), 94-102.

Cabanac, M., Hildebrandt, G., Massonnet, B. \& Strempel, H. (1976). A study of the nycthemeral cycle of behavioural temperature regulation in man. $\mathcal{F}$. Physio., 257, 275292.

Cabanac, M. (1979). Sensory pleasure. The Quarterly Review of Biology, 54(I), I-29.

Downey, J. A., ChIOdi, H. P., \& DaRling, R. C. (1967). Central temperature regulation in the spinal man. F. Appl. Physiol., 22(I), 9I-94.

Downey, J. A., Miller, J. M. \& DARLing, R. C. (I969). Thermoregulatory responses to deep and superficial cooling in spinal man. F. Appl. Physiol., 27(2), 209-2 I2.

Downey, J. A., Huchaba, C. E. \& Darling, R. C. (I97I). The effect of skin and central cooling on human thermoregulation. Int. F. Biometeor., 15(2-4), I7 I-I 75.

Downey, J. A., Huckaba, C. E., Myers, S. J. \& Darling, R. C. (1973). Thermoregulation in the spinal man. F. Appl. Physiol. 34(6), 790-794.

Downey, J. A., Huckaba, C. E., Kelley, P. S., Tam, H. S., Darling, R. C. \& Cheh, H. Y. (1976). Sweating responses to central and peripheral heating in spinal man. F. Appl. Physiol., 40(5), 701-706. 
Engel, P., Rode, F. W., Schindler, W., Attia, M. (1978). Anpassung der Thermoregulation an Gliedmassenverlust. S.F.B. I22, Philyipps-Universität Marburg/L. Band 5, 279-307.

Engel, P., GründL, R. \& AtTIA, M. (1979). Thermal stress strain investigations in work places using comfort/discomfort criteria. European Coal and Steel Community, Luxembourg; Reports No. I $E 2$.

ENGEL, P. \& AtTIA, M. (I980). Thermal stress/strain investigations in work places using comfort/discomfort criteria. European Coal and Steel Community. Luxembourg, Report No. 3, pp. I-44.

ENGEL, P. (I982). Adaptation of thermoregulation to the loss of extremities. In Hildebrandt and Hensel (eds.): Biological Adaptation, Thieme Verlag, Stuttgart. pp. I 98-208.

Gardiner, H. \& Pembrey, M. S. (I9I2). Observations on temperature of man after traumatic section of the spinal cord. Guy's Hospital Reports, 66, 87.

GutTMANN, L., Silver, J. \& Wyndham (I958). Thermoregulation in spinal man. $\mathcal{F}$. Physiol., I42, 406-419.

GutTMANN, L. (1976). Spinal cord injuries: comprehensive management and research. Blackwell Scientific Publications. 2nd edition, Melbourne.

HARDY, J. D. (1972). Peripheral inputs to the central regulator for body temperature. In Itoh, Ogata and Yoshimura (eds.): Advances in climatic physiology, H. pp. 3-2 I. Igaku Shoin Ltd. Tokyo. Springer-Verlag, Heidelberg. New York.

Hensel, H., Brück, K. \& Raths, P. (1973). Homeothermic organisms. In Precht, Christophersen, Hensel and Larcher (eds.): Temperature and life, pp. 503-733. Springer Verlag, Berlin, Heidelberg. New York.

Hensel, H. (1979). Thermoregulation and human comfort. In Fanger and Valbjorn (eds.): Indoor climate, pp. 425-440. Danish Building Research Institute. Copenhagen.

HildebrandT, G., ENGEL, P. \& ATtia, M. (I98I). Temperaturregulation und thermischer Komfort. (Die lokale Messung der thermischen Allaesthesie in der Physikalischen Medizin). Z.f. Phys. Med., Io, 49-6r.

HolmES, G. (I915): Spinal Injuries of warfare. British Med. Journal, 2: 815-82 I.

Hutchinson, J. (I875). Clinical lecture on temperature and circulation after crushing of cervical spinal cord. Lancet, $\mathbf{I}, 715$.

NADEL, R. E. (I977). Problems with temperature regulation during exercise. New York. Academic Press.

PAGET, G. E. (I 885). Case of remarkable risings and fallings of body temperature. Lancet, 2, 4-6.

Pledger, H. G. (1962). Disorders of temperature regulation in acute traumatic tetraplegia. F. Bone $\mathcal{E}$ foint Surgery, 44-B, I IO-I I 2.

Pembrey, M. S. (1897). The temperature of man and animals after section of spinal cord. British Medical fournal, 2, 883-884.

Pollock, L. J., Boshes, B., Chor, H., Finkelman, I., Arief, A. J. \& Brown, M. (I95I). Defects of regulatory mechanisms of autonomic function in injuries to spinal cord. F. Neurophysiology, I4, 85-93.

Rawson, R. O., HaRdy, J. D. (I967).- Sweat inhibition by cutaneous cooling in normal sympathectomized and paraplegic man. F. Appl. Physiol., 22(2), 287-291.

SherRINGTON, C. S. (1924). Notes on temperature after spinal transection with some observations on shivering. Fournal of Physiol., 58, 405-424.

SNELL, E. S. (1954). The relationship between vasomotor response in the hand and heat changes in the body induced by venous infusions of hot or cold saline. F. Physiol. London, 125, 36I-372.

Strempel, H., Hildebrandt, G., Cabanac, M., Massonnet, B. (1976). Tagesrhythmische Einflüsse auf die Thermoregulation unter thermischen Belastungen. In Hildebrandt (ed.): Biologische Rhythmen und Arbeit, Springer Verlag, Wien-New York. pp. 3 I-42.

TigaY, E. L. (1956). Disregulation of temperature control in cervical spinal cord lesions. 5th Paraplegia Conference, p. 8o. Veteran's Administration Hospital, Hines, Illinois.

White, J. C. (1959). Injuries to the cervical cord. Fournal of Bone and foint Surgery. 4I-A, I I.

YouNG, P. Th. (1959). The role of affective processes in learning and motivation. Psychol. Rev., 66, 104-125. 